\title{
|VIIllfle Studi Probabilitas Transmisi dan Karakteristik IV \\ PendIPA pada Molekul DNA G4
}

\author{
Refpo Rahman ${ }^{1 *}$, Efta Yudiarsah ${ }^{2}$ \\ ${ }^{1}$ FMIPA, D3 Laboratorium Sains, Universitas Bengkulu, Bengkulu, Indonesia \\ ${ }^{2}$ Departemen Fisika, FMIPA, Universitas Indonesia, Depok, Indonesia \\ *Email: refporahman@unib.ac.id
}

DOI: https://doi.org/10.33369/pendipa.4.2.51-57

\begin{abstract}
[The study of transmission probability and IV chracteristics of a G4 molecule] In this era, there have been many theoretical and experimental studies conducted to enhance technological development. The development of technology continues to grow rapidly with electronic components that are getting smaller towards nano. Nanotechnology is becoming increasingly interesting because it can be created through DNA that is found in either the human body or other living things. This research was conducted to study DNA transport properties by calculating transmission probabilities and I-V characteristics. The DNA studied is DNA that has been modified consisting of 4 guanine bases arranged stacked to form a square called G4DNA. G4-DNA is composed by having 32 base pairs and connected by electrodes at the end. The transport properties of G4-DNA were studied using the Hamiltonian tight binding approach. Transmission probability is calculated using the method of the Green Function Hamiltonian to determine the possibility of electrons flowing along the DNA pathway. This transmission probability is used in determining the I-V Characteristics based on the Landauer Büttiker formula. The results are obtained that the electron transport process along the G4-DNA molecule is an increase in current to high voltage. The effects of I-V characteristics are seen by affecting the twisting motion frequency up to $5.12 \mathrm{meV}$ which is a significant increase in current. The results of this study can provide information about the characteristics of DNA that can be applied in the future in manufacture of nanotechnology device.
\end{abstract}

Keywords: transport properties; G4 DNA; transmission probability; IV characteristic; Hamiltonian.

\begin{abstract}
ABSTRAK
Di era saat ini, telah banyak penelitian teori dan eksperimen yang dilakukan untuk meningkatkan perkembangan teknologi. Perkembangan teknologi terus berkembang pesat dengan komponen-komponen elektronik yang semakin kecil ke arah nano. Nanoteknologi menjadi semakin menarik karena dapat di ciptakan melalui DNA yang banyak ditemukan baik dalam tubuh manusia ataupun makluk hidup lainnya. Penelitian ini dilakukan untuk mempelajari sifat transport DNA dengan menghitung probabilitas transmisi dan karakteristik I-V. DNA yang dipelajari adalah DNA yang sudah dimodifikasi terdiri dari 4 basa guanine tersusun bertumpuk membentuk persegi yang disebut DNA-G4. DNA G4 disusun dengan memiliki panjang 32 pasangan basa yang ujung-ujungnya dihubungkan dengan elektroda. Sifat transport DNA-G4 dipelajari dengan menggunakan pendekatan Hamiltonian tight binding. Probabilitas transmisi dihitung dengan menggunakan metode green function Hamiltonian untuk mengetahui kemungkinan elektron yang mengalir di sepanjang jalur DNA. Probabilitas transmisi ini digunakan dalam menentukan Karakteristik I-V berdasarkan formula landauer büttiker. Hasilnya diperoleh bahwa terjadinya proses transport elektron di sepanjang molekul DNA-G4 yaitu terjadinya peningkatan arus hingga di tegangan tinggi. Perubahan karakteristik I-V dilihat dengan mempengaruhi frekuensi sudut putarnya hingga $5.12 \mathrm{meV}$ yaitu terjadi peningkatan arus yang cukup signifikan. Hasil penelitian ini dapat memberikan informasi tentang karakteristik DNA yang dapat diterapkan kedepannya dalam pembuatan komponen elektronik berbasis nanoteknologi.
\end{abstract}

Kata kunci: sifat transport; DNA G4; probabilitas transmisi; karakteristik IV; hamiltonian. 


\section{PENDAHULUAN}

Perkembangan teknologi saat ini menuntut para peneliti untuk menciptakan dan mengembangkan piranti elektronik yang lebih efisien dan efektif. Piranti elektronik ini yang dimaksud adalah suatu perangkat berukuran kecil dengan kemampuan yang melebihi kapasitas ukurannya. Salah satu yang dikembangkan peneliti baik teori maupun eksperimen adalah perangkat elektronik berbasis nanoteknologi. DNA merupakan material berukuran nano dengan skala $1 \mathrm{~nm}$ yang dapat digunakan sebagai pendukung perkembangan teknologi berbasis nanoteknologi.

DNA dapat menciptakan kawat nano yang dapat digunakan sebagai template pada piranti elektronik berbasis assemble (Endo dkk., 2009); (Wang dkk., 2013). Penerapan DNA sebagai bahan pembuatan komponen elektronik sudah dikembangkan. Perilaku DNA yang dapat menghantarkan arus listrik telah mendukung perkembangan perangkat elektronik berbasis nanoteknologi seperti biosensor (Amorim dkk., 2015), nanoelektronik (Dugasani dkk., 2016), dan nanofotonik (Reddy dkk., 2017). Serta dalam dunia kesehatan telah dikembangkan alat pendiagnosis dengan menggunakan sensor magnetik seperti MEMS dan NEMS (Khatir dkk., 2015).

Beberapa tahun terakhir sifat transport DNA menarik minat peneliti. DNA tersusun atas basa $\mathrm{A}, \mathrm{T}, \mathrm{G}$, dan $\mathrm{C}$ yang saling terikat kuat dengan ikatan hidrogen serta backbone dihubungkan di ujung-ujung basa. Selain $d s$-DNA ada DNA lain yang digunakan yaitu DNA G4 yang telah diteliti baik secara teori maupun eksperimen. DNA G4 tersusun atas 4 basa guanine yang ditempatkan di sudut-sudut membentuk persegi yang disebut struktur planar. Tumpukan antar struktur planar ini disebut g-quartet. Basa guanine memiliki potensial ionisasi paling rendah dibandingkan basa lainnya sehingga memperlihatkan transport muatan DNA G4 lebih efisien di bandingkan penyusun lainnya yang tidak menggunakan basa guanine (Malakooti dkk., 2012). Proses transport muatan di molekul DNA melibatkan tumpukan $\pi-\pi$ pasangan basa dalam struktur molekul DNA (Eley dan Spivey, 1962). Perubahan spesifik struktur tumpukan $\pi-\pi$ antarbasa dapat mengubah efisiensi proses transport muatan dan konduktivitas listrik. Sehingga, menghasilkan arus listrik di sepanjang molekul DNA.

DNA G4 sangat menarik untuk dipelajari. Prosedur pembuatan DNA G4 dengan mensintesis poly $(\mathrm{dG})-\mathrm{n}(\mathrm{dC})_{20}$ untuk menghasilkan kawat nano. Kawat nano ini memberikan jalan terjadinya proses transport muatan yang dapat digunakan pada perangkat elektronik (Borovok dkk., 2008). DNA G4 memiliki ciri struktural yang menguntungkan dibandingkan $d s$-DNA, sehingga transport muatan dan konduktivitas listrik DNA G4 lebih besar dibandingkan dengan $d s$-DNA (Woiczikowski dkk., 2010). Pada penelitian ini, kami melakukan permodelan secara teoritis dengan menggunakan DNA G4. Model ini dipelajari dengan menggunakan metode Hamiltonian tight binding untuk memodelkan proses transport elektron di dalam molekul DNA. Pendekatan ini digunakan bersama metode fungsi green untuk menghitung probabilitas transmisi dalam mempelajari kemungkinan adanya transport elektron. Temperatur dan frekuensi sudut putar $(\omega)$ memainkan peran penting terhadap proses terjadinya transport elektron di molekul. Temperatur menyebabkan terjadinya fluktuasi sistem di molekul yang merusak koheren transport elektron (Guo dan Xiong, 2009).

\section{METODE PENELITIAN}

\section{Waktu dan Lokasi Penelitian}

Penelitian ini dilakukan tahun 2017 berlokasi

di laboratorium Cisco FMIPA Universitas Indonesia.

\section{Model DNA G4}

Pemodelan molekul DNA G4 terdiri dari 4 basa guanine yang disusun bertumpuk membentuk persegi dengan panjang 32 pasangan basa. Molekul DNA G4 dihubungkan dengan elektroda di ujung-ujungnya, seperti yang dirangkai pada Gambar 1,

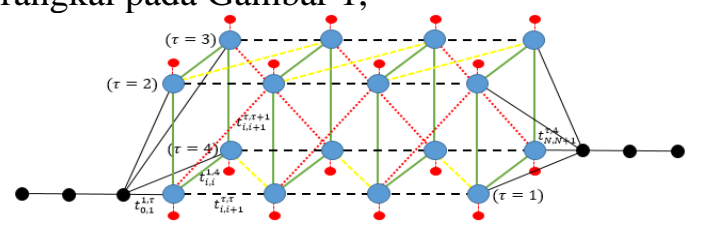

Gambar 1. Permodelan molekul DNA G4.

Simbol biru, merah, dan hitam berturut-turut basa guanine, backbone dan elektroda. Garisgaris sebagai jalur transport elektron. 
Proses transport elektron pada molekul DNA G4 di Gambar 1, dapat dipelajari dengan menggunakan pendekatan Hamiltonian tight binding. Terjadinya proses transport elektron karena adanya lompatan elektron di dalam molekul DNA G4. Ada beberapa proses lompatan elektron di dalam molekul antara lain lompatan antar-basa dalam satu untai (intrastrand), lompatan antar-basa di untai yang berbeda (interstrand) dan lompatan antar basa dan untai yang sama (Watson-Crick) (Suhendro dkk, 2010). Model tight binding dapat digunakan untuk menghitung struktur pita elektronik yang terikat kuat di dalam molekul DNA. Hamiltonian tight binding molekul DNA G4 pada penelitian ini dapat ditulis dengan persamaan berikut (Rahman dkk., 2018),

$$
\begin{aligned}
H_{D N A} & =\sum_{i=1}^{L}\left\{\sum_{\tau=1}^{4}\left\{\left(\varepsilon_{i}^{\tau}+\phi_{i}^{\tau}\right) i, \tau\right\rangle\left\langle i, \tau\left|+t_{i, i+1}^{\tau, \tau}\right| i, \tau\right\rangle\langle i+1, \tau|\right\} \\
& +\sum_{\tau=1}^{4}\left\{B_{i}^{\tau, q}|i, \tau\rangle\left\langle i, q\left|+t_{i, i}^{\tau, q}\right| i, \tau\right\rangle\langle i, q|\right\} \\
& \left.+\Sigma_{\tau=1}^{4}\left\{\tau_{i, i}^{\tau, \tau+1}|i, \tau\rangle\left\langle i, \tau+1\left|+t_{i, i+1}^{\tau, \tau+1}\right| i, \tau\right\rangle\langle i+1, \tau+1|\right\}\right]+ \text { h.c. } \\
& \varepsilon_{i}^{\tau} \text { dan } B_{i}^{\tau} \text { berturut-turut merupakan energi }
\end{aligned}
$$
on-site basa guanine dan backbone. $t_{i, i+1}^{\tau, \tau}, t_{i, i+1}^{\tau, \tau+1}, t_{i, i}^{\tau, \tau} \quad$ berturut-turut merupakan konstanta lompatan elektron secara intrastrand, interstrand dan Watson-Crick di molekul DNA G4. Sedangkan, jarak dan sudut putar antar pasangan basa molekul DNA G4 sebesar $3.25 \mathrm{~nm}$ dan $30^{\circ}$. Pengaruh lingkungan memainkan peran penting terhadap proses terjadinya transport elektron. Parameter konstanta energi on-site basa guanine dan backbone $\boldsymbol{\varepsilon}_{\mathbf{i}}^{\boldsymbol{\tau}}$ dan $B_{\mathbf{i}}^{\boldsymbol{q}}$ serta parameter konstanta lompatan elektron $\left(\mathrm{t}_{\mathrm{xy}}\right)$ intrastrand, interstrand dan Watson Crick dapat dirangkai pada Tabel 1 dan 2 berikut,

Tabel 1. Parameter on-site energi basa guanine dan backbone (Suhendro dkk., 2010).

\begin{tabular}{ccc}
\hline $\begin{array}{c}\text { On-site } \\
\text { Energi }\end{array}$ & $\begin{array}{c}\boldsymbol{\varepsilon}_{\mathbf{i}}^{\boldsymbol{\tau}} \\
(\mathbf{e V})\end{array}$ & $\begin{array}{c}\boldsymbol{B}_{\mathbf{i}}^{\boldsymbol{q}} \\
(\mathbf{e V})\end{array}$ \\
\hline Guanine & 7.84 & - \\
\hline Backbone & - & 9.36 \\
\hline
\end{tabular}

Tabel 2. Parameter konstanta lompatan elektron $\left(t_{x y}\right)$ (Suhendro dkk., 2010).

\begin{tabular}{ccccc}
\hline $\begin{array}{c}\text { Basa } \\
(\mathrm{XY})\end{array}$ & $\begin{array}{c}\boldsymbol{t}_{\boldsymbol{x}, \boldsymbol{y}}^{\boldsymbol{a}} \\
(\mathbf{e V})\end{array}$ & $\begin{array}{c}\boldsymbol{t}_{\boldsymbol{x}, \boldsymbol{y}}^{\boldsymbol{} \boldsymbol{y}} \\
(\mathrm{eV})\end{array}$ & $\begin{array}{c}\boldsymbol{t}_{\boldsymbol{x}, \boldsymbol{y}}^{\boldsymbol{p}} \\
(\mathrm{eV})\end{array}$ & $\begin{array}{c}\boldsymbol{b}_{\boldsymbol{x}, \boldsymbol{y}} \\
(\mathrm{eV})\end{array}$ \\
\hline $\mathrm{G}, \mathrm{G}$ & 0.30 & 0.14 & - & 0.0334 \\
\hline
\end{tabular}

\section{Fungsi Green}

Fungsi green digunakan dalam perhitungan berbagai jenis sistem kuantum. Metode fungsi green digunakan untuk menentukan probabilitas transmisi $T(E)$ dengan mengoperasikan fungsi gelombang pada Hamiltonian tight binding pers (1). Adapun fungsi green yang digunakan adalah fungsi green retarded (Challis dkk., 2003) yang ditulis dengan,

$$
G^{R}\left(\begin{array}{c}
\rho \\
)
\end{array}\right)=\left[(\varepsilon(k)+i \eta) I-H_{D N A}-\sum_{l}^{R}-\sum_{r}^{R}\right]^{-1},
$$

$H_{D N A}$ merupakan Hamiltonian sistem. $\varepsilon(\vec{k})$ merupakan energi on-site basa guanine sebagai fungsi $\vec{k}, \eta$ merupakan bilangan bernilai positif yang sangat kecil, dan $\Sigma_{l(r)}^{R}$ merupakan selfenergy yang menjelaskan interaksi elektron antara elektroda kiri-DNA dan DNA-elektroda kanan. Fungsi green $\left[G^{R}(\vec{k})\right]$ digunakan untuk menghitung probabilitas transmisi dengan menggunakan hubungan Fisher Lee (Kang dkk., 2016) yang dinyatakan dengan,

$$
\begin{gathered}
T(E)=\operatorname{Tr}\left[\Gamma_{l} G^{R}(E) \Gamma r G^{A}(E)\right] \text { dengan, } \\
\Gamma_{l(r)}=i\left[\sum_{l(r)}^{R}-\sum_{l(r)}^{A}\right]
\end{gathered}
$$

\section{Formula Landauer Büttiker}

Probabilitas transmisi sebagai fungsi energi elektron $T(E)$ yang diperoleh dari pers. (3) digunakan untuk menghitung arus sebagai fungsi tegangan. Arus dihitung dengan menggunakan formula Landauer Büttiker (Maciá dkk., 2005),

$$
\begin{gathered}
I=\frac{2 e}{h} \int_{-\infty}^{+\infty} d E T(E)\left[f\left(E-\varepsilon_{F}+e V / 2\right)-f\left(E-\varepsilon_{F}-e V / 2\right)\right] \text { (4) } \\
I \text { adalah arus, } V \text { adalah tegangan, } \varepsilon_{F}
\end{gathered}
$$
merupakan energi fermi, dan $f\left(E-\varepsilon_{F} \pm \frac{e V}{2}\right)$ merupakan fungsi distribusi fermi.

\section{HASIL DAN PEMBAHASAN}

Pada bagian ini, kita akan menganalisis perhitungan transport elektron dari hasil perhitungan probabilitas transmisi dan karakteristik IV di molekul DNA G4. Transport elektron di molekul DNA G4 diamati dengan memberikan pengaruh frekuensi sudut putar $(\omega)$ dari $0.51 \mathrm{meV}-5.12 \mathrm{meV}$ dan temperatur sebesar $4.2 \mathrm{~K}$ dan $300 \mathrm{~K}$ untuk mengetahui perubahan probabilitas transmisi dan karakteristik IV. 


\section{Probabilitas Transmisi}

Probabilitas transmisi dihitung untuk mengetahui kemungkinan adanya proses transport elektron yang terjadi di molekul DNA. Molekul DNA G4 dihubungkan dengan elektroda agar terjadi proses transport elektron dari elektrodamolekul-elektroda. Adanya proses transport elektron inilah menjadi pengukuran probabilitas transmisi di sepanjang molekul DNA.

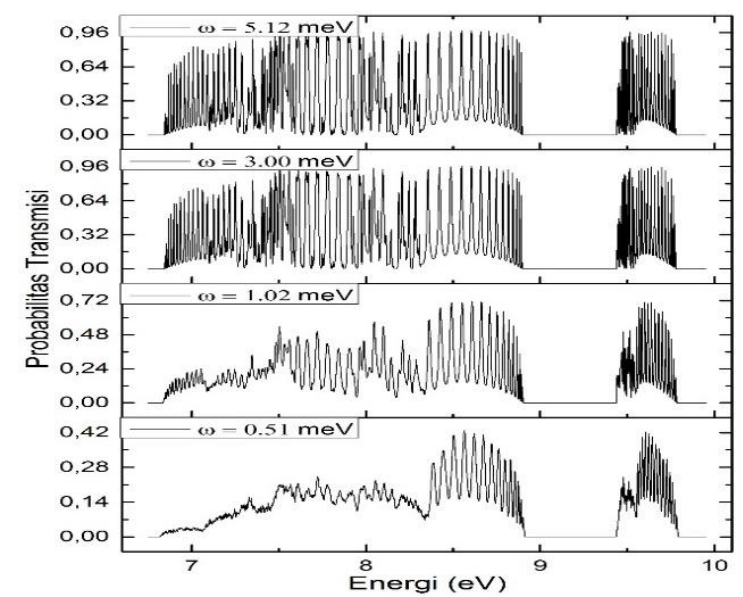

(a)

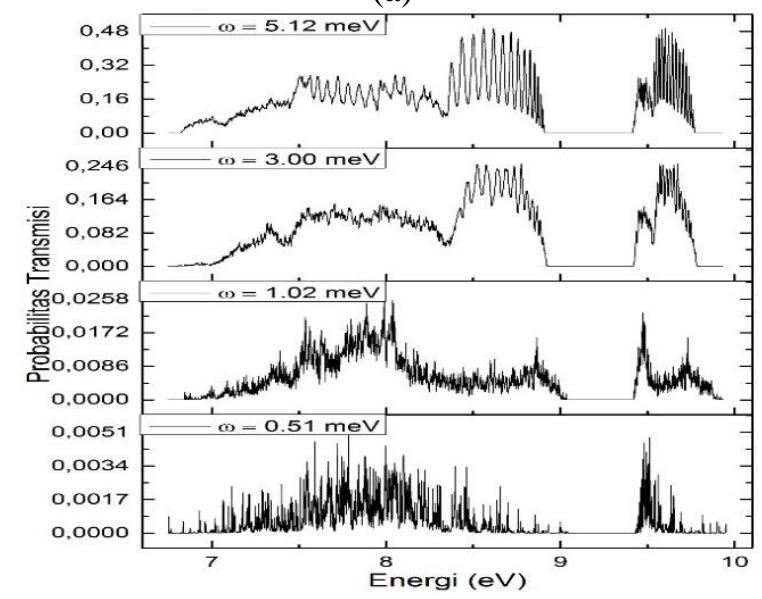

(b)

Gambar 2. Probabilitas Transmisi sebagai fungsi energi dengan frekuensi sudut putar $(\omega)$ sebesar $0.51,1.02,3.00$ dan $5.12 \mathrm{meV}$ pada temperatur (a) $4.2 \mathrm{~K}$ dan (b) $300 \mathrm{~K}$.

Berdasarkan hasil perhitungan yang sudah dilakukan menunjukkan adanya proses transport elektron yang terjadi di molekul DNA G4. Gambar (2) memperlihatkan distribusi elektron di setiap tingkatan energi dari energi $6.35-10 \mathrm{eV}$. Distribusi elektron ini dapat dilihat dari dua pita energi pada rentang 6.35-8.8 eV dan rentang 9.4-
9.7 eV yang memiliki probabilitas transmisi tinggi. Dua pita energi ini diperoleh dari adanya energi on-site basa guanine dan backbone di Tabel 1. Gambar (2) juga menunjukkan grafik perilaku yang sama terdapat probabilitas transmisi bernilai nol disekitar energi 8.8-9.4 eV. Transmisi nol ini sering disebut gap. Kehadiran gap ini disebabkan adanya interaksi antar basa guanine di molekul DNA G4.

.Molekul DNA pada umumnya dapat berpilin ataupun berputar. Pilinan pada molekul DNA dapat mempengaruhi mobilitas elektron di sepanjang molekul DNA. Pada penelitian ini, kami memvariasikan nilai frekuensi sudut putar $(\omega)$ dari 0.51-5.12 meV untuk mengetahui perubahannya terhadap mobilitas elektron di molekul DNA. Hasilnya dapat dilihat pada Gambar 2, terjadi perubahan probabilitas transmisi di $\mathrm{T}=4.2 \mathrm{~K}$ dan $\mathrm{T}=300 \mathrm{~K}$. Perubahan ini memberikan dampak yang sangat baik yaitu terjadi peningkatan probabilitas transmisi di dua pita energi 6.35-8.8 eV dan 9.4-9.7 eV. Probabilitas transmisi tertinggi yang dihasilkan mencapai 0.96 pada rentang energi 8.4-8.8 eV dan 9.4-9.7 eV di frekuensi sudut putar $(\omega) 5.12 \mathrm{meV}$. Variasi nilai frekuensi sudut putar $(\omega)$ ini memberikan dampak yang sangat besar dan signifikan terhadap probabilitas transmisi dikarenakan nilai $\omega$ mempengaruhi putaran DNA menjadi lebih cepat, sehingga mobilitas elektron di dalam molekul DNA bergerak lebih cepat.

Perhitungan selanjutnya memberikan pengaruh temperatur terhadap molekul DNA sebesar $4.2 \mathrm{~K}$ dan $300 \mathrm{~K}$. Pengaruh temperatur ini menyebabkan timbulnya fonon dijalur transport elektron yang mempengaruhi mobilitas elektron disepanjang molekul DNA saat transport dari elektroda-molekul-elektroda. Hasil probabilitas transmisi di bawah pengaruh temperatur dapat dilihat perbandingannya pada Gambar 2. (a) dan (b). Temperatur $300 \mathrm{~K}$ memberikan gangguan besar terhadap mobilitas elektron di dalam molekul DNA menyebabkan probabilitas transmisi mengalami penurunan. Berdasarkan data yang dihasilkan terjadi penurunan probabilitas transmisi yang sangat besar di tingkat energi 8-9 eV dan 9.4-9.8 eV untuk seluruh nilai frekuensi sudut putar $(\omega)$. Terjadinya penurunan ini karena temperatur mengakibatkan pergeseran keadaan molekul dan menyebabkan fluktuasi 
termal yang memperburuk transport muatan DNA (Rahman dan Yudiarsah, 2019); (Joe dkk., 2013). Karakteristik IV

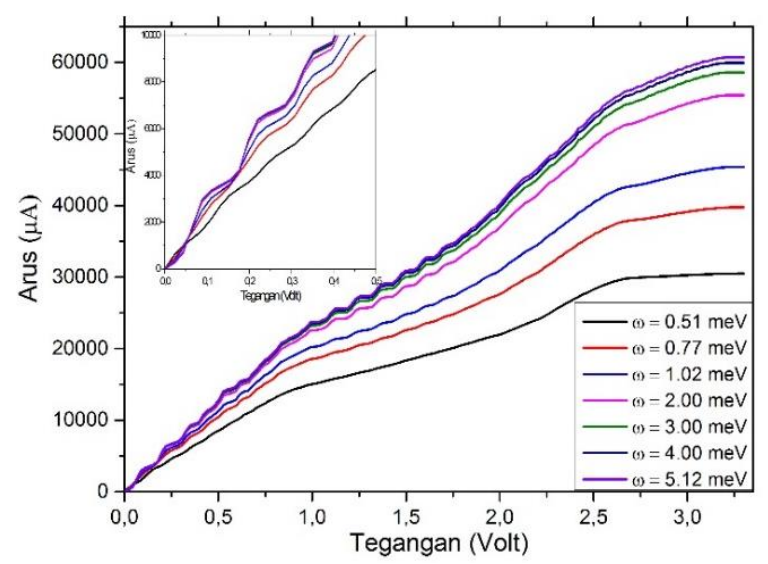

(a)

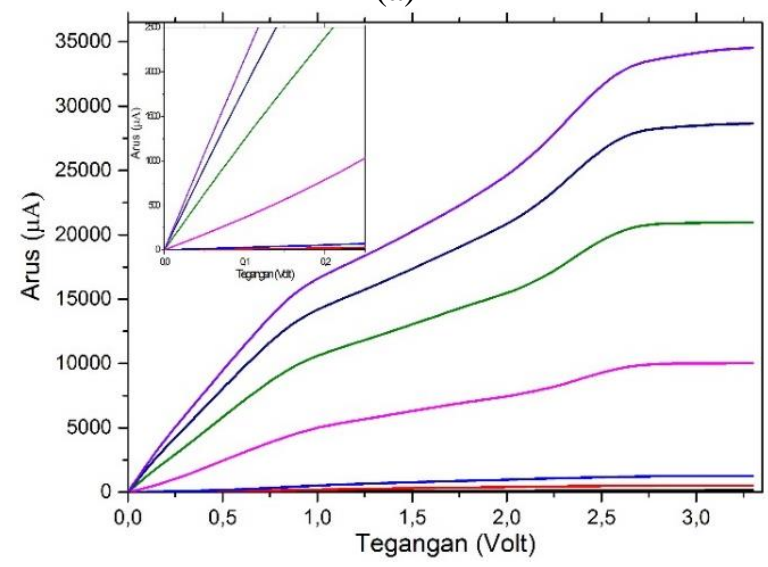

(b)

Gambar 3. Arus $(\mu A)$ sebagai fungsi tegangan (Volt) pada temperatur (a) $4.2 \mathrm{~K}$ dan (b) $300 \mathrm{~K}$ dengan memvariasikan frekuensi sudut $\operatorname{putar}(\omega)$ sebesar 0.51-5.12 meV.

Pada bagian ini, akan menampilkan hasil perhitungan karakteristik IV yaitu arus listrik (I) sebagai fungsi tegangan (V). Formula Landauer Büttiker di hitung untuk mengetahui keadaan arus listrik di dalam molekul DNA. Probabilitas transmisi yang diperoleh perhitungan sebelumnya memperlihatkan karakteristik arus listriknya. Semakin besar probabilitas transmisi nya, maka semakin besar arus listrik yang dihasilkan. Hasil perhitungan karakteristik IV dapat diamati pada Gambar 3 yang menampilkan arus listrik sebagai fungsi tegangan disepanjang molekul DNA diukur dari elektroda kiri-molekul-elektroda kanan.

Ada beberapa pengukuran, pertama, mengamati hasil perhitungan pada Gambar 3 (a), grafik ini memperlihatkan karakteristik IV di temperatur $4.2 \mathrm{~K}$ dengan variasi nilai frekuensi sudut putarnya $(\omega)$ dari $0.51-5.12 \mathrm{meV}$. Hasilnya terjadi peningkatan arus listrik di frekuensi sudut putar $(\omega)$ terbesar. Peningkatan arus listrik ini memiliki kecendrungan yang sama dengan perhitungan probabilitas transmisi. Hal ini dikarenakan elektron yang bergerak dari elektroda-molekul-elektroda sangat cepat mengakibatkan arus listrik menguat di sepanjang molekul. Probabilitas transmisi yang besar memberikan dampak terhadap arus listrik yang semakin tinggi. Kita amati grafik arus listrik $\omega=$ $0.51 \mathrm{meV}$ menghasilkan arus listrik sebesar \pm $30000 \mu A$, sedangkan frekuensi tertinggi $\omega=5.12$ meV menghasilkan arus listrik sebesar \pm 60000 $\mu A$. Keadaan ini memperlihatkan terjadinya kenaikan arus listrik dua kali lipatnya dari hasil frekuensi terkecil. Secara umum, semakin besar frekuensi sudut putar $(\omega)$, maka semakin besar arus listriknya. Peningkatan arus listrik ini bisa juga kita amati saat di tegangan rendah seperti yang diperlihatkan pada grafik kecil di dalam Gambar 3.(a) yaitu arus mengalami peningkatan perlahan hingga ke tegangan tinggi.

Selanjutnya, melakukan perbandingan perhitungan dengan memberikan pengaruh temperatur sebesar $4.2 \mathrm{~K}$ dan $300 \mathrm{~K}$. Hasilnya dapat dilihat bahwa pengaruh temperatur hingga $300 \mathrm{~K}$ menyebabkan arus listrik mengalami penurunan. Hal ini dikarenakan timbulnya fonon disekitar molekul yang memberikan gangguan terhadap pergerakan elektron. Keadaan ini memberikan efek buruk terhadap karakteristik arus listriknya. Jika dibandingan berdasarkan frekuensi sudut putarnya, diperoleh $\omega=0.51$ meV awalnya sebesar $\pm 30000 \mu A$ menjadi \pm 20 $\mu A$ dan $\omega=5.12 \mathrm{meV}$ awalnya sebesar \pm 60000 $\mu A$ menjadi $\pm 35000 \mu A$. Keadaan ini menunjukkan penurunan yang signifikan terhadap keadaan state di molekul DNA. Perhitungan ini sesuai dengan hasil perhitungan yang dikerjakan pada penelitian sebelumnya yaitu pengaruh temperature menyebabkan terjadinya perubahan keadaan pita energi elektron yang menyebabkan ketidakteraturan elektron di dalam molekul DNA (Rahman dan Yudiarsah, 2019). Hasil lainnya, pada temperatur ruangan $300 \mathrm{~K}$ arus maksimum menurun di tegangan tinggi. Penurunan ini karena adanya distorsi molekul yang menyebabkan 
vibrasi struktural termal dan sudut putar elastik elektron meningkat (Joe dkk., 2013).

\section{KESIMPULAN}

Sifat transport elektron molekul DNA G4 telah dipelajari. Permodelan DNA G4 dihitung dengan menggunakan Hamiltonian tight binding untuk menentukan probabilitas transmisi dan karakteristik IV. Dari hasil perhitungan yang telah dilakukan, pengaruh frekuensi sudut putar $(\omega)$ hingga $5.12 \mathrm{meV}$ menyebabkan probabilitas transmisi mengalami peningkatan hingga 0.96 di dua pita energi dan menyebabkan arus mengalami peningkatan dari $30.000 \mu A$ hingga $\pm 60000 \mu A$ ditegangan tinggi. Perhitungan lainnya di bawah pengaruh temperatur $300 \mathrm{~K}$ menyebabkan timbulnya fonon di molekul DNA yang dapat menurunkan probabilitas transmisi dan karakteristik IV. Probabilitas transmisi yang mengalami penurunan diperlihatkan dengan keadaan elektron yang berkurang di pita energi hingga 0.0051. Turunnya probabilitas transmisi ini mengakibatkan arus juga menurun yaitu $\omega=0.51 \mathrm{meV}$ awalnya sebesar $\pm 30000 \mu A$ menjadi $\pm 20 \mu A$ dan $\omega=$ $5.12 \mathrm{meV}$ awalnya sebesar $\pm 60000 \mu A$ menjadi $\pm 35000 \mu \mathrm{A}$.

\section{UCAPAN TERIMA KASIH}

Ucapan terima kasih diberikan kepada pihak-pihak yang telah membantu dalam penelitian ini. Ucapan terima kasih juga kepada UPP-IPD FMIPA Universitas Indonesia yang telah memberikan izin penggunaan laboratorium Cisco.

\section{DAFTAR PUSTAKA}

Amorim, R.G., and Scheicher, R.H.. (2015). Silicene as a new potential DNA sequencing device, Nanotechnology, vol. 26, no. 15 , p. 154002.

Borovok, N., Molotsky, T., Ghabboun, J., Porath, D., and Kotlyar, A. (2008). Efficient procedure of preparation and properties of long uniform G4-DNA nanowires, Anal. Biochem., vol. 374, pp. 71-78.

Challis, dkk (2003). The green of Function. Physics Today 56 (12), pp. 41-46

Dugasani, S.R.., Hwang, T., Kim, J.A., Gnapareddy, B., Kim, T., and Park, S.H.. (2016). Metal electrode dependent field effect transistors made of lanthanide iondoped DNA crystals. J. Phys. D. Appl. Phys., vol. 49, no. 10, p. 105501.

Eley, D.D and Spivey, D.I. (1962) Semiconductivity of organic substances. Part 9.-Nucleic acid in the dry state, Trans. Faraday Soc., vol. 58, no. 0, pp. 411-415.

Endo, M., and Sugiyama, H. (2009). Chemical Approaches to DNA Nanotechnology. ChemBioChem 10, 2420 - 2443

Guo, A.M., and Xiong, S.J. (2009). Effects of contact and efficient charge transport in G4-DNA molecules, Phys. Rev. B Condens. Matter Mater. Phys., vol. 80, no. 3, pp. 1-5.

Joe, Y.S., Lee, S.H., Hedin, E.R., and Kim, Y.D. (2013). Temperature and magnetic field effects on electron transport through DNA molecules in a two-dimensional fourchannel system, J Nanosci Nanotechnol, vol. 13, no. 6, pp. 3889-3896.

Kang, D et al. (2016). Charge transport and magnetoresistance of G4-DNA molecular device modulated by counter ions and dephasing effect, Phys. Lett. A, vol. 380, no. 7-8, pp. 977-982.

Khatir, N.M., Abdul, M., and Banihashemian, S.M.. (2015). Influences of magnetic fields on current-voltage characteristics of goldDNA-gold structure with variable gaps. Mater. Sci. Semicond. Process., vol. 36, pp. 134-139.

Maciá, M., Triozon, F., and Roche, S. (2005). "Contact-dependent effects and tunneling currents in DNA molecules, Phys. Rev. B Condens. Matter Mater. Phys., vol. 71, no. 11, pp. 2-5.

Malakooti, S., Hedin, E.R.., Kim, Y.D.., and Joe, Y.S. (2012). Enhancement of charge transport in DNA molecules induced by the next nearest-neighbor effects. J. Appl. Phys., vol. 112, no. 9.

Rahman, R., dan Yudiarsah, E. (2019). Modeling of the temperature and magnetic 
field dependence on the density of states of G4-DNA molecules. IOP.Conf.series: Materials Science and Engineering 496 012016.

Reddy, M.S.P., Lee, Y.W., Jeong, S.H., and Park, C. (2017). Effect of illumination and frequency dependent series resistance and interface state densities on the electrical properties of DNA-CTMA/p-GaN biohybrid Schottky photodiode, Polym. Test., vol. 59, pp. 107-112.

Suhendro, D.K., Yudiarsah, E., and Saleh, R. (2010). Effect of phonons and backbone disorder on electronic transport in DNA, Phys. B Condens. Matter, vol. 405, no. 23, pp. 4806-4811.
Wang, F., Willner, B., and Willner, I. (2013). DNA Nanotechnology with onedimensional self-ssembled Nanostructures. Current opinion in Biotechnology 24 page: $562-574$.

Woiczikowski, P.B., Kuba, T., Gutírrez, R., Cuniberti, G., and Elstner, M. (2010), Structural stability versus conformational sampling in biomolecular systems: Why is the charge transfer efficiency in G4-DNA better than in double-stranded DNA?. $J$. Chem. Phys., vol. 133, no. 3. 